\title{
Changes of the Time Intervals Specific to Calendar Anomalies: the Case of TOQ Effect on Bucharest Stock Exchange
}

\author{
Stefanescu Razvan \\ rstefanescu@ugal.ro \\ Dumitriu Ramona \\ rdumitriu@,ugal.ro \\ Dunarea de Jos University of Galati, Romania
}

\begin{abstract}
The Turn-of-the-quarter (TOQ) Effect is a calendar anomaly consisting in abnormal returns occurring in a specific time interval, that starts in the $\mathrm{m}^{\text {th }}$ last trading day of a quarter $(\mathrm{BQ}-\mathrm{m})$ and ends in the $\mathrm{n}^{\text {th }}$ last trading day of a quarter $(\mathrm{BQ}+\mathrm{n})$. As many other anomalies, the TOQ Effect is not necessary persistent in time, so the interval [BQ-m; $\mathrm{BQ}+\mathrm{n}]$ could experience some changes. This paper explores such changes for the time intervals specific to the Turn-of-the-quarter (TOQ) Effect using the daily values of three main indexes from Bucharest Stock Exchange: BET, BET-FI and BET-XT. We investigate the presence of this calendar anomaly in two periods: January 2007 - December 2013 and January 2014 - July 2020. For the first one we found abnormal returns within the time intervals [BQ-3; BQ+1], in the case of BET, [BQ-6; BQ+3], in the case of BET-FI and for a single trading day (BQ-2), in the case of BET-XT. For the second period, the results indicate abnormal returns within the time intervals [BQ-5; BQ+5], in the case of BET and BET-XT, and [BQ-5; BQ+6], in the case of BET-FI. These changes could be linked to the behaviors of investors who want to exploit or to avoid the abnormal returns, but also to the different circumstances associated to the two periods.
\end{abstract}

Keywords: Persistence in time of the calendar anomalies, TOQ Effect, Romanian capital market

JEL: G40, G10, G14

\section{Introduction}

The TOQ (Turn-of-the-quarter) Effect is a calendar anomaly materialized in abnormal returns that occur in a time interval that starts in the last trading days of a quarter and it ends in the first trading days of the next quarter. In fact, the TOQ Effect could be viewed as a particular, and sometimes more salient, the case of TOM Effect. As in the case of TOM Effect, the presence of abnormal returns could be studied for a whole TOQ interval or individually, for each day composing it (Lakonishok \& Smidt, 1988; Agrawal \& Tandon, 1994). In fact, a TOM (or a TOQ) interval is not strictly defined and in the specialized literature there could be found various variants (Kunkel et al., 2003; McConnell \& Xu, 2008; Giovanis, 2014).

Among the most invoked explanations for TOM Effect (and, obviously, for TOQ Effect) there are those linked to the stock markets' liquidity, to the practice of portfolio "window dressing" or to the public announcements impact on prices. The stock markets' liquidity has a significant influence on stock returns (Amihud \& Mendelson, 1986; Brennan \& Subrahmanyam, 1996; Datar et al., 1998; Chordia et al., 2001; Jun et al., 2003; Baker \& Stein, 2004). During a TOQ interval there are some circumstances, linked to the regularity of some payments, which could affect the liquidity from some financial markets (Ogden, 1990; Ziemba, 1991; Booth et al., 2001; Etula et al., 2020). In many countries, at the beginning or the end of quarters, the individual investors which receive cash in the forms of wages, dividends or interests could be motivated to buy stocks. However, in the same period, some 
institutional investors could be motivated to sell stocks as they face liquidity problems because of the wages, dividends or interests they have to pay.

The practice of portfolio "window dressing" was observed among the institutional investors that want to offer, promising images of their performances during the TOQ intervals, when their results are usually examined by the clients. The stocks which experienced low returns are sold and, instead, there are bought stocks which had high returns recently. After the period of examination ended, the portfolio could be rebalanced by repurchasing or reselling. Such transactions could generate abnormal returns for some days included in TOQ intervals (Thaler, 1987; Ritter \& Chopra, 1989; Lakonishok et al. 1991; Wiley \& Zumpano, 2009; Arsad et al., 2011).

Empirical researches found significant stocks' prices reactions to the public announcements (Ball \& Kothari, 1991; Kim \& Verrecchia, 1991; Lee, 1992; Mitchell \& Mulherin, 1994; Chan, 2003; Barber, \& Odean, 2008). In many countries, in the TOQ intervals there are scheduled important news about the macroeconomic performances or about the companies' earnings. The investors' reactions to such announcements could lead to abnormal stock returns (Patell \& Wolfson, 1981; Thaler, 1987; Nikkinen et al., 2006; Gerlach, 2007).

As many other calendar anomalies, TOM and TOQ Effects could experience significant changes in time (Wong et al., 2006; Kumar, 2015; Robins \& Smith, 2017; Dumitriu \& Stefanescu, 2019; Khan \& Rabbani, 2019). Various forms of changes that occurred in the calendar anomalies were described in the specialized literature: attenuation, disappearing, going to reverse etc. (Dimson and Marsh, 1999; Schwert, 2003; Marquering et al., 2006; Chordia et al., 2014; Auer and Rottmann, 2019). A less approached type of change consists in the modifications of limits that characterize the time interval specific to a calendar anomaly (Stefanescu \& Dumitriu, 2019; Stefanescu \& Dumitriu, 2020).

In this paper we approach the modification of time interval specific to the TOQ Effect on Bucharest Stock Exchange (BSE) for the period January 2007 - July 2020. In order to capture the changes experienced by this calendar anomaly we perform our investigation for two sub-samples of data:

- first sub-sample, with daily values of three indexes of BSE covering the period of January 2007 - December 2013;

- second sub-sample, with daily values of four indexes of BSE covering the period of January 2014 - July 2020.

The rest of this paper is organized as it follows: the second part describes the data and methodology used to identify the abnormal returns that occur during turn-of-the-quarter intervals, the third part presents the empirical results and the fourth part concludes.

\section{Data and Methodology}

\subsection{Description of the Data}

In this investigation about the changes experienced by the TOQ Effect in BSE we employ the daily closing values of three major indexes: BET, BET-FI and BET-XT. The data from January 2007 to July 2020 are provided by BSE. As we mentioned before we split the sample of data into two sub-samples:

- the first sub-sample, from January 2007 to December 2013;

- the second sub-sample, from January 2014 to July 2020.

For each index, we compute the logarithmic returns $\left(\mathrm{r}_{\mathrm{i}, \mathrm{t}}\right)$ using the formula:

$$
r_{j, t}=\left[\ln \left(P_{j, t}\right)-\ln \left(P_{j, t-1}\right)\right] \times 100
$$

in which $P_{j, t}$ and $P_{j, t-1}$ are the closing prices of index $j$ on the days $t$ and $t-1$, respectively. 
Table 1. Descriptive statistics of the returns for the two sub-samples

\begin{tabular}{|c|c|c|c|c|c|c|}
\hline Variable & Mean & Median & S.D. & Min & Max & $\begin{array}{c}\text { Jarque-Bera } \\
\text { test }\end{array}$ \\
\hline \multicolumn{7}{|c|}{ First sub-sample } \\
\hline BET & -0.0150 & 0.0458 & 1.83 & -13.1 & 10.6 & $3909.72^{* * *}$ \\
\hline BET-FI & -0.0445 & 0.0001 & 2.62 & -16.1 & 13.8 & $3306.99 * * *$ \\
\hline BET-XT & -0.0326 & 0.0335 & 1.96 & -12.7 & 11.0 & $3293.55^{* * *}$ \\
\hline \multicolumn{7}{|c|}{ Second sub-sample } \\
\hline BET & 0.0156 & 0.0433 & 1.02 & -11.9 & 6.8 & 41744.11*** \\
\hline BET-FI & 0.0177 & 0.0222 & 0.98 & -9.6 & 10.4 & $32377.62^{* * *}$ \\
\hline BET-XT & 0.0148 & 0.0490 & 0.97 & -11.3 & 6.5 & $44860.33^{* * *}$ \\
\hline
\end{tabular}

Note: $* * *$ means significant at 0.01 levels.

The descriptive statistics of the returns for the two sub-samples are reported in the Table 1. There are some significant differences between the two periods (Figure 1). In the case of first sub-sample, as a result of the BSE significant decline, the averages for all indexes were negative.

The recovery that started in 2014 was reflected, in the case of second sub-sample, in positive averages for all indexes. The values of standard deviations of the returns decreased from the first to the second sub-sample, suggesting that period January 2007 - December 2013 were more turbulent than period January 2014 - July 2020 (however, since the spring of 2020, the consequences of COVID-19 induced major turbulences on BSE as in many stock markets from around the world). The Jarque-Bera tests indicate, for both sub-samples, that returns of the indexes didn't follow normal distributions.

r_BET

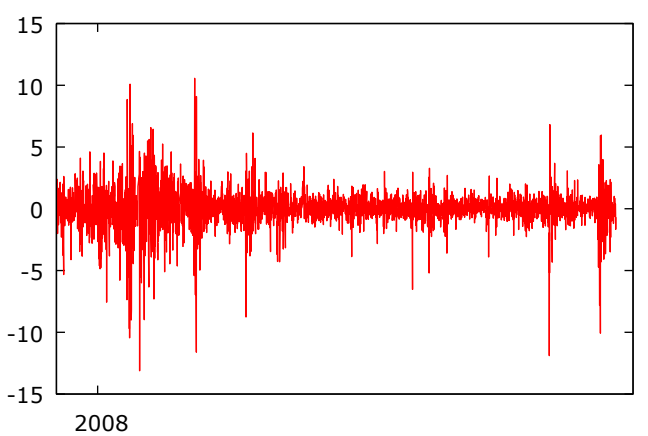

r_BET_XT

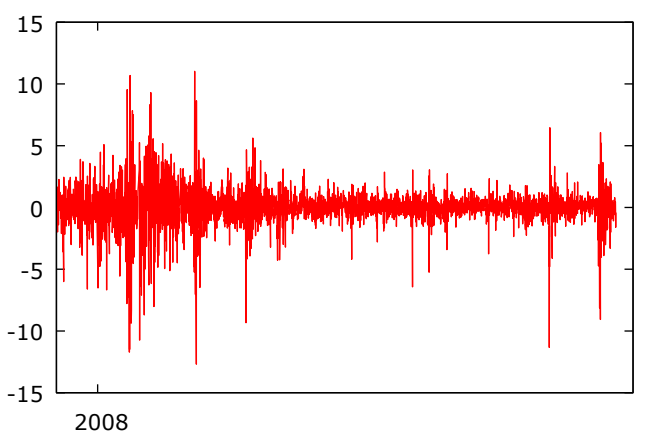

r_BET_FI

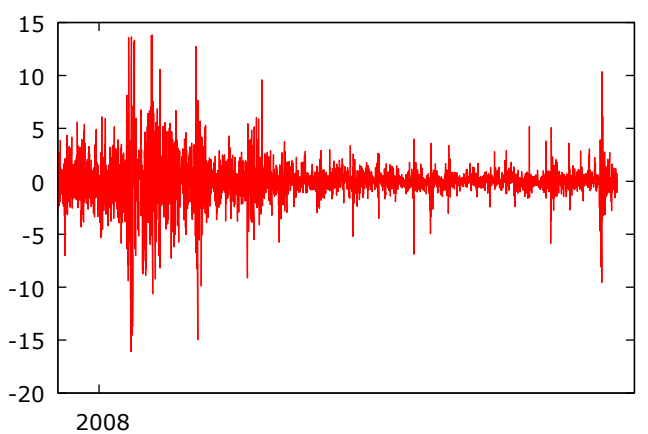

Figure 1. Logarithmic returns of the three indexes for the period January 2007 - July 2020 Source of the daily closing values of indexes: https://www.bvb.ro 
Initially, for our investigation on presence of the TOQ effect we take into consideration an interval that includes the last six trading days (BQ-m, $1 \leq \mathrm{m} \leq 6)$ of a quarter and the first six trading days of next quarter $(B Q+n, 1 \leq n \leq 6)$.

$$
\left(\begin{array}{l}
B Q-6 ; B Q-5 ; B Q-4 ; B Q-3 ; B Q-2 ; B Q-1 ; \\
B Q+1 ; B Q+2 ; B Q+3 ; B Q+4 ; B Q+5 ; B Q+6
\end{array}\right)
$$

The averages of returns for the trading days contained in this time interval are presented in the Table 2. For both sub-samples, the low and high returns alternate.

Table 2. Average returns for the trading days of [BQ-6; BQ+6] time interval

\begin{tabular}{|l|l|l|l|l|l|l|}
\hline \multirow{2}{*}{$\begin{array}{l}\text { Trading } \\
\text { day }\end{array}$} & First sub-sample & \multicolumn{4}{l|}{ Second sub-sample } \\
\cline { 2 - 7 } & BET & BET-FI & BET-XT & BET & BET-FI & BET-XT \\
\hline BQ-6 & -0.312 & -0.120 & -0.181 & 0.375 & 0.277 & 0.330 \\
\hline BQ-5 & 0.177 & 0.260 & 0.186 & -0.424 & -0.365 & -0.365 \\
\hline BQ-4 & -0.111 & -0.616 & -0.253 & 0.464 & 0.269 & 0.417 \\
\hline BQ-3 & -0.569 & -0.501 & -0.541 & -0.013 & 0.150 & 0.006 \\
\hline BQ-2 & 0.055 & 0.174 & 0.122 & 0.156 & -0.087 & 0.111 \\
\hline BQ-1 & 0.544 & 0.274 & 0.423 & 0.253 & 0.489 & 0.286 \\
\hline BQ+1 & 0.377 & 0.614 & -0.094 & 0.114 & -0.083 & 0.079 \\
\hline BQ+2 & 0.807 & 0.339 & 0.668 & 0.162 & 0.108 & 0.169 \\
\hline BQ+3 & -0.408 & -0.355 & -0.455 & 0.061 & 0.009 & 0.037 \\
\hline BQ+4 & 0.220 & 0.057 & 0.179 & -0.104 & -0.004 & -0.079 \\
\hline BQ+5 & 0.167 & -0.472 & 0.027 & 0.293 & 0.344 & 0.288 \\
\hline BQ+6 & -0.245 & -0.100 & -0.190 & -0.125 & -0.335 & -0.150 \\
\hline
\end{tabular}

For the identification of abnormal returns from the TOQ intervals we use regressions with dummy variables associated to $\mathrm{BQ}-\mathrm{m}$ and $\mathrm{BQ}+\mathrm{n}$ trading days. For the trading days from the end of a quarter (BQ-m) we define the dummy variables:

$$
D B Q_{-m, t}=\left\{\begin{array}{l}
1, \text { if the day } t \text { is the } m^{\text {th }} \text { last trading day of a quarter } \\
0, \text { otherwise }
\end{array}\right.
$$

where $1 \leq \mathrm{m} \leq 6$.

For the trading days from the beginning of a quarter $(B Q+n)$ we use a category of dummy variables defined as:

$$
D B Q_{+n, t}=\left\{\begin{array}{l}
1, \text { if the day } t \text { is the } n^{\text {th }} \text { trading day of a quarter } \\
0, \text { otherwise }
\end{array}\right.
$$

where $1 \leq \mathrm{n} \leq 6$.

As a preliminary step for the investigations by regressions, we have to study if the returns of indexes are stationary using the Augmented Dickey - Fuller (ADF) unit root tests for two variants: with and without constant (Dickey \& Fuller, 1979; Dickey \& Fuller, 1981). The results, reported by the Table 3, indicate, for both sub-samples, that returns of all indexes were stationary. 
Table 3. Results of ADF tests

\begin{tabular}{|l|r|r|r|r|}
\hline \multirow{2}{*}{ Index } & $\begin{array}{c}\text { Test without constant } \\
\text { Number of } \\
\text { lags }\end{array}$ & Test statistic & $\begin{array}{c}\text { Tumber of } \\
\text { lags }\end{array}$ & \multirow{2}{*}{ Test statistic } \\
\hline First sub-sample \\
\hline BET & 10 & $-10.9210^{* * *}$ & 10 & $-10.9212^{* * *}$ \\
\hline BET-FI & 10 & $-11.6421^{* * *}$ & 10 & $-11.6486^{* * *}$ \\
\hline BET-XT & 10 & $-10.8992^{* * *}$ & 10 & $-10.9070^{* * *}$ \\
\hline Second sub-sample & 10 & $-11.3570^{* * *}$ & 10 & $-11.3658^{* * *}$ \\
\hline BET & 9 & $-11.7189^{* * *}$ & 9 & $-11.733^{* * *}$ \\
\hline BET-FI & 9 & $-11.4658^{* * *}$ & 9 & $-11.4725^{* * *}$ \\
\hline BET-XT & 9
\end{tabular}

Notes: Akaike (1974) Information Criterion was used to identify the optimum number of lags; *** means significant at 0.01 levels.

\subsection{Methodology}

The abnormal returns of the TOQ intervals are to be identified in the framework provided by Engle (1982) and Bollerslev (1986) GARCH $(1,1)$ model with two equations:

a. the conditional mean equation;

b. the conditional variation equation.

a. The conditional mean equation is:

$$
r_{j, t}=\mu_{0}+\sum_{i=1}^{6} \lambda_{i} \times D B Q_{-i, t}+\sum_{i=1}^{6} \rho_{n} \times D B Q_{+i, t}+\sum_{i=1}^{q} \xi_{i} \times r_{j, t-i}+\varepsilon_{t}
$$

where:

- $\mu_{0}$ is a constant term;

- $\lambda_{\text {i }}$ represents a coefficient associated to the dummy variable DBQ ${ }_{-m, t}$ which captures the influence on the returns of the last $\mathrm{m}^{\text {th }}$ trading day of a quarter;

- $\varrho_{i}$ represents a coefficient associated to the dummy variable DBQ ${ }_{+n, t}$ which captures the influence on the returns of the $\mathrm{n}^{\text {th }}$ trading day of a quarter;

- $\xi_{\mathrm{i}}$ is a coefficient of the $\mathrm{i}$-order lagged returns of the dependent variable;

- q represents the number of lagged returns;

- $\varepsilon_{t}$ is the error term that follows a normal distribution with zero mean and a time varying variance $h_{t}$ :

$$
\varepsilon_{t} \mid I_{t-1} \sim N\left(O, h_{t}\right)
$$

If the value of a coefficient associated to a dummy variable is significant positive or negative we consider that in the corresponding trading day the returns are abnormal high, respectively, low.

b. The conditional variation equation has the form:

$$
h_{t}=\omega+\alpha_{1} \times \varepsilon_{t-1}^{2}+\beta_{1} \times h_{t-1}
$$

where:

- $\omega$ is a constant term; 
- $\alpha_{1}$ represents a coefficient associated to the lagged squared residuals;

- $\beta_{1}$ represents a coefficient associated to the lagged variance.

\section{Empirical Results}

The Table 4 reports the coefficients of GARCH equations for the first sub-sample. For the BET index we obtained a significant negative value of the coefficient $\lambda_{3}$ (meaning abnormal low returns for the trading day BQ-3) and significant positive values of the coefficients $\lambda_{2}, \lambda_{1}$ and $\varrho_{1}$ (meaning abnormal high returns for the trading days BQ-2, BQ-1 and $\mathrm{BQ}+1)$.

In the case of BET-FI index, the coefficients $\lambda_{6}$ and $\varrho_{3}$ are significant negative (meaning abnormal low returns for the trading days BQ-6 and BQ+3), while the coefficients $\lambda_{2}$ and $\varrho_{1}$ are significant positive (meaning abnormal high returns for the trading days BQ-2 and $\mathrm{BQ}+1)$. For the BET-XT index we obtained a significant positive value of the coefficient $\lambda_{2}$ (meaning abnormal high returns for the trading day BQ-2).

Table 4. Coefficients of GARCH equations for the first sub-sample

\begin{tabular}{|c|c|c|c|}
\hline \multirow{2}{*}{ Coefficient } & \multicolumn{3}{|c|}{ Index } \\
\hline & BET & BET-FI & BET-XT \\
\hline \multirow[b]{2}{*}{$\mu_{0}$} & 0.032 & $0.070^{*}$ & 0.026 \\
\hline & $(0.028)$ & $(0.038)$ & $(0.030)$ \\
\hline \multirow[b]{2}{*}{$\lambda_{6}$} & -0.218 & $-0.449 *$ & -0.129 \\
\hline & (0.193) & $(0.266)$ & $(0.224)$ \\
\hline \multirow{2}{*}{$\lambda_{5}$} & 0.347 & 0.239 & 0.222 \\
\hline & $(0.211)$ & $(0.254)$ & $(0.224)$ \\
\hline \multirow{2}{*}{$\lambda_{4}$} & -0.062 & -0.334 & -0.003 \\
\hline & (0.198) & $(0.258)$ & $(0.216)$ \\
\hline \multirow{2}{*}{$\lambda_{3}$} & $-0.447 * *$ & -0.255 & -0.257 \\
\hline & $(0.199)$ & $(0.264)$ & $(0.224)$ \\
\hline \multirow{2}{*}{$\lambda_{2}$} & $0.475^{* *}$ & $0.451^{*}$ & $0.694 * * *$ \\
\hline & $(0.227)$ & $(0.250)$ & $(0.228)$ \\
\hline \multirow{2}{*}{$\lambda_{1}$} & $0.476^{* *}$ & -0.049 & 0.081 \\
\hline & $(0.203)$ & $(0.249)$ & $(0.217)$ \\
\hline \multirow[b]{2}{*}{$\varrho_{1}$} & $0.477 * *$ & $0.816^{* * *}$ & -0.062 \\
\hline & $(0.188)$ & $(0.254)$ & $(0.205)$ \\
\hline \multirow[b]{2}{*}{$\varrho_{2}$} & 0.229 & -0.044 & 0.121 \\
\hline & $(0.205)$ & $(0.266)$ & $(0.217)$ \\
\hline \multirow[b]{2}{*}{ @3 } & 0.053 & $-0.592 * *$ & -0.325 \\
\hline & $(0.215)$ & $(0.263)$ & $(0.220)$ \\
\hline \multirow[b]{2}{*}{$\varrho_{4}$} & 0.053 & 0.238 & 0.283 \\
\hline & $(0.206)$ & $(0.265)$ & $(0.214)$ \\
\hline \multirow[b]{2}{*}{$\varrho_{5}$} & 0.195 & -0.073 & 0.149 \\
\hline & (0.197) & $(0.253)$ & $(0.212)$ \\
\hline \multirow[b]{2}{*}{$\varrho_{6}$} & -0.208 & 0.148 & -0.071 \\
\hline & $(0.199)$ & $(0.259)$ & $(0.211)$ \\
\hline \multirow[b]{2}{*}{$\xi_{1}$} & $0.083^{* * *}$ & $0.135^{* * *}$ & $0.106^{* * *}$ \\
\hline & $(0.026)$ & $(0.025)$ & $(0.026)$ \\
\hline \multirow[b]{2}{*}{$\omega$} & $0.062^{* * *}$ & $0.040^{* * *}$ & $0.046^{* * *}$ \\
\hline & $(0.014)$ & $(0.012)$ & (0.014) \\
\hline \multirow[b]{2}{*}{$\alpha_{1}$} & $0.255^{* * *}$ & $0.154^{* * *}$ & $0.186^{* * *}$ \\
\hline & $(0.027)$ & $(0.020)$ & $(0.025)$ \\
\hline \multirow{2}{*}{$\beta_{1}$} & $0.745^{* * *}$ & $0.846^{* * *}$ & $0.814 * * *$ \\
\hline & $(0.024)$ & $(0.018)$ & $(0.024)$ \\
\hline
\end{tabular}

Notes: Standard errors are within parentheses; ***, ** and * mean significant at $0.01,0.05$ and 0.1 levels, respectively. 
The coefficients of GARCH regressions for the second sub-sample are presented in the Table 5. For all three indexes the coefficients $\lambda_{5}$ are significant negative (meaning abnormal low returns for the trading day BQ-5), while the coefficients $\varrho_{5}$ are significant positive (meaning abnormal high returns for the trading day $\mathrm{BQ}+5$ ). In the case of BET-FI index we also obtained significant positive value of the coefficient $\lambda_{1}$ (meaning abnormal high returns for the trading day BQ-1) and a significant negative value of the coefficient Q6 (meaning abnormal low returns for the trading day $\mathrm{BQ}+6)$.

Table 5. Coefficients of GARCH equations for the second sub-sample

\begin{tabular}{|c|c|c|c|}
\hline \multirow{2}{*}{ Coefficient } & \multicolumn{3}{|c|}{ Index } \\
\hline & BET & BET-FI & BET-XT \\
\hline$\mu_{0}$ & $\begin{array}{r}0.079 * * * \\
(0.019)\end{array}$ & $\begin{array}{r}0.060 * * * \\
(0.019)\end{array}$ & $\begin{array}{r}0.082^{* * *} \\
(0.017)\end{array}$ \\
\hline$\lambda_{6}$ & $\begin{array}{r}0.119 \\
(0.177)\end{array}$ & $\begin{array}{l}-0.092 \\
(0.132)\end{array}$ & $\begin{array}{r}0.072 \\
(0.165)\end{array}$ \\
\hline$\lambda_{5}$ & $\begin{array}{r}-0.406^{* * *} \\
(0.138) \\
\end{array}$ & $\begin{array}{r}-0.247 * * \\
(0.126) \\
\end{array}$ & $\begin{array}{r}-0.367 * * * \\
(0.124) \\
\end{array}$ \\
\hline$\lambda_{4}$ & $\begin{array}{r}0.139 \\
(0.148)\end{array}$ & $\begin{array}{r}0.097 \\
(0.128) \\
\end{array}$ & $\begin{array}{r}0.135 \\
(0.133)\end{array}$ \\
\hline$\lambda_{3}$ & $\begin{array}{r}0.088 \\
(0.145)\end{array}$ & $\begin{array}{r}0.003 \\
(0.135)\end{array}$ & $\begin{array}{r}0.081 \\
(0.136)\end{array}$ \\
\hline$\lambda_{2}$ & $\begin{array}{r}0.211 \\
(0.143)\end{array}$ & $\begin{array}{l}-0.190 \\
(0.130)\end{array}$ & $\begin{array}{r}0.142 \\
(0.134)\end{array}$ \\
\hline$\lambda_{1}$ & $\begin{array}{r}0.082 \\
(0.154) \\
\end{array}$ & $\begin{array}{r}0.310^{* *} \\
(0.127) \\
\end{array}$ & $\begin{array}{r}0.106 \\
(0.149) \\
\end{array}$ \\
\hline$\varrho_{1}$ & $\begin{array}{r}0.223 \\
(0.140)\end{array}$ & $\begin{array}{r}0.048 \\
(0.123) \\
\end{array}$ & $\begin{array}{r}0.172 \\
(0.130)\end{array}$ \\
\hline$\varrho_{2}$ & $\begin{array}{c}-0.048 \\
(0.145)\end{array}$ & $\begin{array}{l}-0.189 \\
(0.125)\end{array}$ & $\begin{array}{l}-0.072 \\
(0.133)\end{array}$ \\
\hline$\varrho_{3}$ & $\begin{array}{c}-0.124 \\
(0.140)\end{array}$ & $\begin{array}{l}-0.166 \\
(0.133)\end{array}$ & $\begin{array}{c}-0.132 \\
(0.129)\end{array}$ \\
\hline$\varrho_{4}$ & $\begin{array}{l}-0.128 \\
(0.127)\end{array}$ & $\begin{array}{l}-0.115 \\
(0.126)\end{array}$ & $\begin{array}{c}-0.123 \\
(0.118)\end{array}$ \\
\hline Q5 & $\begin{array}{c}0.267 * * \\
(0.128)\end{array}$ & $\begin{array}{r}0.263^{* *} \\
(0.122)\end{array}$ & $\begin{array}{l}0.226^{*} \\
(0.123)\end{array}$ \\
\hline Q6 & $\begin{array}{l}-0.080 \\
(0.126)\end{array}$ & $\begin{array}{r}-0.384 * * * \\
(0.123)\end{array}$ & $\begin{array}{c}-0.126 \\
(0.115)\end{array}$ \\
\hline$\omega$ & $\begin{array}{r}0.081 * * * \\
(0.019)\end{array}$ & $\begin{array}{r}0.076^{* * *} \\
(0.013)\end{array}$ & $\begin{array}{r}0.074 * * * \\
(0.016)\end{array}$ \\
\hline$\alpha_{1}$ & $\begin{array}{r}0.373 * * * \\
(0.054)\end{array}$ & $\begin{array}{r}0.275^{* * *} \\
(0.037) \\
\end{array}$ & $\begin{array}{r}0.399 * * * \\
(0.053) \\
\end{array}$ \\
\hline$\beta_{1}$ & $\begin{array}{r}0.617 * * * \\
(0.052) \\
\end{array}$ & $\begin{array}{r}0.665^{* * *} * \\
(0.035)\end{array}$ & $\begin{array}{r}0.592^{* * *} \\
(0.050)\end{array}$ \\
\hline
\end{tabular}

Notes: Standard errors are within parentheses; $* * *, * *$ and $*$ mean significant at $0.01,0.05$ and 0.1 levels, respectively.

Based on the abnormal returns found for the two sub-samples we established time intervals specific to the TOQ Effect (Table 6).

Table 6. Time intervals specific to the TOQ Effect

\begin{tabular}{|l|r|r|}
\hline \multirow{2}{*}{ Index } & \multicolumn{2}{|c|}{ Period } \\
\cline { 2 - 3 } & January 2007 - December 2013 & January 2014 - July 2020 \\
\hline BET & {$[\mathrm{BQ}-3 ; \mathrm{BQ}+1]$} & {$[\mathrm{BQ}-5 ; \mathrm{BQ}+5]$} \\
\hline BET-FI & {$[\mathrm{BQ}-6 ; \mathrm{BQ}+3]$} & {$[\mathrm{BQ}-5 ; \mathrm{BQ}+6]$} \\
\hline BET-XT & $(\mathrm{BQ}-2)$ & {$[\mathrm{BQ}-5 ; \mathrm{BQ}+5]$} \\
\hline
\end{tabular}




\section{Conclusions}

The results of our investigation indicate, for each index, changes in time intervals specific to the TOQ Effect (Table 6). Such modifications could be explained by the behavior of traders who became aware about abnormal returns from the beginning or the end of a quarter. Those who want to buy stocks could prefer the trading days with abnormal low returns, while avoiding the days with abnormal high returns. Obviously, the traders who want to sell could have opposite behaviors. As a result, the abnormal returns moved to other trading days. Such changes could be boosted by the passing from the turbulent period of 2007-2013 to the more quiet period of $2014-2020$.

We found, among the three indexes, some similarities regarding the TOQ Effects. For the first sub-sample, all of them had abnormal high returns on BQ-2. In the case of second sub-sample, all three indexes had abnormal low returns on BQ-5 and they had abnormal high returns on $\mathrm{BQ}+5$. There were also some differences, especially between the BET-FI index and the other two indexes. For both sub-samples, the time intervals specific to the TOQ Effect and the number of trading days with abnormal returns are larger in the case of BET-FI index. Such differences could be linked to the constituents of these indexes. While BET and BET-XT captures the general tendency of BSE, BET-FI is a sectorial index, which reflects the evolution of stocks prices of some investment entities.

As in the case of other calendar anomalies, the changes experienced by TOQ Effect could raise questions about the success of investment strategies designed to exploit the knowledge on abnormal returns. The persistence in time of calendar effects was quite often invoked in the dispute between adepts of the Behavioral Finance and partisans of the Fama (1970) Efficient Market Hypothesis (EMH). It is hard to use as an argument against EMH calendar anomaly that experienced significant changes (Fama, 1998; Fama \& French, 2008).

As some studies concluded, many calendar anomalies from the emergent markets, including TOM Effect, are not necessary similar to those from the developed markets (Georgantopoulos et al., 2011; Werner \& Teresita, 2015; Kayacetin \& Lekpek, 2016; Arendas \& Kotlebova, 2019). In these circumstances, this investigation could be extended to the TOQ Effects on some European developed capital markets.

\section{References}

1. Agrawal, A., \& Tandon, K. (1994). Anomalies or illusions? Evidence from stock markets in eighteen countries. Journal of International Money and Finance, 13(1), 83-106.

2. Akaike, $H$. (1974). A new look at the statistical model identification. IEEE transactions on automatic control, 19(6), 716-723.

3. Amibud, Y., \& Mendelson, H. (1986). Liquidity and stock returns. Financial Analysts Journal, 42(3), 43-48.

4. Arendas, P., \& Kotlebova, J. (2019). The Turn of the Month Effect on CEE Stock Markets. International Journal of Financial Studies, 7(4), 57.

5. Arsad, Z. B., Chuah, S. A. S., \& Nordin, S. N. M. (2011). Predictability of Turn-of-the-Month Effect at Stock Markets in Malaysia, South Korea and Japan. South Korea and Japan (August 21, 2011).

6. Auer, B. R. \& Rottmann, H. (2019). Have capital market anomalies worldwide attenuated in the recent era of high liquidity and trading activity?. Journal of Economics and Business, 103, 61-79.

7. Baker, M., \& Stein, J. C. (2004). Market liquidity as a sentiment indicator. Journal of Financial Markets, 7(3), 271-299.

8. Ball, R., \& Kothari, S. (1991). Security returns around earnings announcements. Accounting Review, 66(4), 718-738.

9. Barber, B. M., \& Odean, T. (2008). All that glitters: The effect of attention and news on the buying behavior of individual and institutional investors. The Review of Financial Studies, 21(2), 785-818. 
10. Bollerslev, T. (1986). Generalized autoregressive conditional beteroskedasticity. Journal of Econometrics, 31(3), 307-327.

11. Booth, G. G., Kallunki, J. P., \& Martikainen, T. (2001). Liquidity and the turn-of-the-month effect: evidence from Finland. Journal of International Financial Markets, Institutions and Money, 11(2), 137146.

12. Brennan, M. J., \& Subrahmanyam, A. (1996). Market microstructure and asset pricing: On the compensation for illiquidity in stock returns. Journal of Financial Economics, 41(3), 441-464.

13. Chan, W. S. (2003). Stock price reaction to news and no-news: drift and reversal after headlines. Journal of Financial Economics, 70(2), 223-260.

14. Chordia, T., Roll, R. \& Subrabmanyam, A. (2001). Market liquidity and trading activity. The Journal of Finance, 56(2), 501-530.

15. Chordia, T., Subrabmanyam, A., \& Tong, Q. (2014). Have capital market anomalies attenuated in the recent era of high liquidity and trading activity?. Journal of Accounting and Economics, 58(1), 41-58.

16. Datar, V. T., Naik, N. Y., \& Radcliffe, R. (1998). Liquidity and stock returns: An alternative test. Journal of Financial Markets, 1(2), 203-219.

17. Dickey, D. A., \& Fuller, W. A. (1979). Distribution of the estimators for autoregressive time series with a unit root. Journal of the American Statistical Association, 74(366a), 427-431.

18. Dickey, D. A., \& Fuller, W. A. (1981). Likelihood ratio statistics for autoregressive time series with a unit root. Econometrica: Journal of the Econometric Society, 1057-1072.

19. Dimson, E., \& Marsh, P. (1999). Murphy's Law and market anomalies. The Journal of Portfolio Management, 25(2), 53-69.

20. Dumitriu, R., Stefanescu, R., 2019 Changes in the behavior of stocks returns during the turn-of-thequarter, The XII International \& Interdisciplinary Scientific Conference VANGUARD SCIENTIFIC INSTRUMENTS IN MANAGEMENT 2019. Available at: bttps://papers.ssrn.com/sol3/papers.cfm?abstract_id $=3469118$

21. Engle, R. F. (1982). Autoregressive conditional heteroscedasticity with estimates of the variance of United Kingdom inflation. Econometrica: Journal of the Econometric Society, 987-1007.

22. Etula, E., Rinne, K., Suominen, M., \& Vaittinen, L. (2020). Dash for cash: Monthly market impact of institutional liquidity needs. The Review of Financial Studies, 33(1), 75-111.

23. Fama, E.F., 1970. Efficient Capital Markets: A Review of Theory and Empirical Work. Journal of Finance, 25(2), pp. 383-417.

24. Fama, E. F. (1998). Market efficiency, long-term returns, and behavioral finance. Journal of Financial Economics, 49(3), 283-306.

25. Fama, E. F., \& French, K. R. (2008). Dissecting anomalies. The Journal of Finance, 63(4), 16531678.

26. Georgantopoulos, A. G., Kenourgios, D., \& Tsamis, A. (2011). Calendar anomalies in emerging Balkan equity markets. International Economics and Finance Journal, 6(1), 67-82.

27. Gerlach, J. R. (2007). Macroeconomic news and stock market calendar and weather anomalies. Journal of Financial Research, 30(2), 283-300.

28. Giovanis, E. (2014). The Turn-of-the-Month-Effect: Evidence from Periodic Generalized Autoregressive Conditional Heteroskedasticity (PGARCH) Model. International Journal of Economic Sciences and Applied Research, 7(3), 43-61.

29. Jun, S. G., Marathe, A., \& Shawky, H. A. (2003). Liquidity and stock returns in emerging equity markets. Emerging Markets Review, 4(1), 1-24.

30. Kayacetin, V., \& Lekpek, S. (2016). Turn-of-the-month effect: New evidence from an emerging stock. market. Finance Research Letters, 18, 142-157.

31. Khan, M. S. R. \& Rabbani, N. (2019). Market conditions and calendar anomalies in Japanese stock returns. Asia-Pacific Financial Markets, 26(2), 187-209.

32. Kim, O., \& Verrecchia, R. E. (1991). Trading volume and price reactions to public announcements. Journal of Accounting Research, 29(2), 302-321. 
33. Kumar, S. (2015). Turn-of-month effect in the Indian currency market. International Journal of Managerial Finance.

34. Kunkel, R. A., Compton, W. S., \& Beyer, S. (2003). The turn-of-the-month effect still lives: the international evidence. International Review of Financial Analysis, 12(2), 207-221.

35. Lakonishok, J., \& Smidt, S. (1988). Are seasonal anomalies real? A ninety-year perspective. The Review of Financial Studies, 1(4), 403-425.

36. Lakonishok, J., Shleifer, A., Thaler, R., \& Vishny, R. (1991). Window Dressing by Pension Fund Managers. The American Economic Review, 81(2), 227-231.

37. Lee, C. M. (1992). Earnings news and small traders: An intraday analysis. Journal of Accounting and Economics, 15(2-3), 265-302.

38. McConnell, J. J., \& Xu,W. (2008). Equity Returns at the Turn of the Month. Financial Analysts Journal, 64(2), 49-64.

39. Mitchell, M. L., \& Mulherin, J. H. (1994). The impact of public information on the stock market. The Journal of Finance, 49(3), 923-950.

40. Nikeinen, J., Sablström, P., \& Äijö, J. (2006). Turn-of-the-month and intramonth effects: Explanation from the important macroeconomic news announcements. Journal of Futures Markets: Futures, Options, and Other Derivative Products, 27(2), 105-126.

41. Ogden, J. P. (1990). Turn-of-month evaluations of liquid profits and stock returns: A common explanation for the monthly and January effects. The Journal of Finance, 45(4), 1259-1272.

42. Patell, J. M., \& Wolfson, M. A. (1981). The ex ante and ex post price effects of quarterly earnings announcements reflected in option and stock prices. Journal of Accounting Research, 434-458.

43. Ritter, J. R. \& Chopra, N. (1989). Portfolio rebalancing and the turn-of-the-year effect. The Journal of Finance, 44(1), 149-166.

44. Robins, R. P., \& Smith, G. P. (2017). On unmodeled breaks in the Turn of the year, Turn of the month, and January effects. Financial Review, 52(4), 725-747.

45. Schwert, G. W. (2003). Anomalies and market efficiency. Handbook of the Economics of Finance, 1, 939-974.

46. Stefanescu, R. \& Dumitriu, R. (2019). The extended Friday the $13^{\text {th }}$ effect in the London Stock Exchange. The XII International \& Interdisciplinary Scientific Conference VANGUARD SCIENTIFIC INSTRUMENTS IN MANAGEMENT 2019. Available at: bttps://papers.ssm.com/sol3/papers.cfm?abstract_id $=3484517$

47. Stefanescu, R, \& Dumitriu, R. (2020). The passing from the classical to the extended form of the Holiday Effect on the Euronext. The XIII International \& Interdisciplinary Scientific Conference VANGUARD SCIENTIFIC INSTRUMENTS IN MANAGEMENT 2020. Available at: bttps://papers.ssm.com/sol3/Papers.cfm?abstract_id $=3657040$

48. Thaler, R. H. (1987). Anomalies: weekend, holiday, turn of the month, and intraday effects. Journal of Economic Perspectives, 1(2), 169-177.

49. Werner, K. R., \& Teresita, A. Y. (2015). El efecto fin de mes en los principales mercados accionarios latinoamericanos. Contaduría y Administración, 60(1), 53-86.

50. Wiley, J. A., \& Zumpano, L. V. (2009). Institutional investment and the turn-of-the-month effect: evidence from REITs. The Journal of Real Estate Finance and Economics, 39(2), 180-201.

51. Wong, W. K., Agarwal, A., \&Wong, N. T. (2006). The Disappearing Calendar Anomalies in the Singapore Stock Market. Lahore Journal of Economics, 11(2).

52. Ziemba, W. T. (1991). Japanese security market regularities: Monthly, turn-of-the-month and year, boliday and golden week effects. Japan and the World Economy, 3(2), 119-146. 